\title{
REGIONALNA SPECJALIZACJA PRODUKCJI ROLNEJ W POLSCE
}

\section{REGIONAL SPECIALIZATION OF AGRICULTURAL PRODUCTION IN POLAND}

\section{Agnieszka TŁUCZAK}

\author{
Uniwersytet Opolski \\ Wydział Ekonomiczny \\ ul. Ozimska 46a, 45-058 Opole \\ atluczak@uni.opole.pl
}

Zarys treści: Rolnictwo jest bardzo specyficznym sektorem gospodarki. Jedną z głównych cech wyróżniających produkcję rolną jest jej charakter i silne uzależnienie od warunków środowiskowych. Warunki te określają w dużym stopniu charakter produkcji rolnej oraz jej strukturę (roślinną/zwierzęcą). Akcesja Polski do UE w 2004 r. oraz dostęp do unijnych środków finansowych częstokroć powodowały zmianę aktualnego profilu działalności gospodarstwa rolnego. W związku z tym wydaje się uzasadnione zbadanie zmian specjalizacji produkcji rolnej w Polsce po 2004 roku. Celem niniejszego opracowania jest zatem odpowiedź na następujące pytania: (1) Czy istnieje i jak silne jest stężenie poszczególnych głównych rodzajów produkcji rolnej w Polsce, (2) Jaki jest charakter tej produkcji w wybranych jednostkach przestrzennych.

Analizę przeprowadzono na podstawie danych dotyczących wielkości towarowej produkcji rolnej w latach 2004-2014 z Banku Danych Lokalnych Głównego Urzędu Statystycznego w Polsce ${ }^{1}$. Specjalizację określono przy użyciu indeksu specjalizacji regionalnej Krugmana.

Słowa kluczowe: indeks Krugmana, rolnictwo, specjalizacja produkcji.

\section{Wstęp}

Pojęcie specjalizacji jest szeroko wykorzystywane w teorii rozwoju regionalnego i lokalnego. Obecnie często dąży się do specjalizacji w różnych dziedzinach produkcji, upatrując w tym możliwości uzyskania wyższych dochodów. Istotną cechą regionu ekonomicznego jest jego specjalizacja, którą można określić jako posiadanie bardzo wyraźnie określonego profilu wytwórczego, z niezwykle silnie rozwiniętym działem gospodarki lub rodzajem produkowanych dóbr. Specjalizacja może też wynikać z oryginalności danego obszaru i określa wówczas ten rodzaj działalności, który występuje jedynie tylko w tym konkretnym regionie (Miłek i Nowak 2014).

\footnotetext{
1 Bank Danych Lokalnych, https://bdl.stat.gov.pl/BDL/dane/wymiary (10.10.2015).
} 
Specjalizacja produkcji jest jednym ze sposobów polepszenia efektów działalności przedsiębiorstw działających w ramach danej branży. W rolnictwie pojęcie specjalizacji pozwala odpowiedzieć na pytanie, co najlepiej w danym gospodarstwie rolnym produkować i sprzedawać, aby osiągnąć jak największe zyski. Zatem celem specjalizacji jest zwiększenie ilości i jakości produkcji towarowej, wzrost wydajności pracy, osiąganie lepszej opłacalności produkcji i dochodów z gospodarstwa rolnego. W konsekwencji wzrost specjalizacji produkcji prowadzi do zwiększenia jej dochodowości (Dziwulski 2012).

Specjalizacja regionalna jest najczęściej identyfikowana przez porównanie struktury produkcji rolnej regionu do uśrednionej struktury wszystkich badanych regionów (kraju). Region posiada wysoką specjalizację regionalną, gdy jego struktura branżowa produkcji rolnej różni się od przeciętnej dla regionów (kraju) (Bąk i in. 2008). Stopień specjalizacji regionalnej ustala się za pomocą specjalnie skonstruowanych indeksów specjalizacji (niepodobieństwa) (Ratajczak 2011). Istotą specjalizacji w założeniu H. Innesa jest skupienie się na wybranej grupie towarów (Grosse 2002; Landes 2000), które mogą być najbardziej konkurencyjne na rynkach zewnętrznych. Korzyści wynikające ze specjalizacji zapewnia wysoka jakość wytwarzanych towarów, stale doskonalona organizacja produkcji oraz obniżanie jej kosztów (Miłek i Nowak 2014).

\section{Cel i metoda badań}

Głównym celem badań było wskazanie regionów (województw) specjalizujących się w danym rodzaju produkcji rolnej w Polsce. Badania zostały przeprowadzone na podstawie danych z Banku Danych Lokalnych GUS dotyczących towarowej produkcji rolnej obejmujących lata 2004-2014.

W literaturze przedmiotu prezentowanych jest wiele wskaźników/indeksów specjalizacji. Na uwagę zasługują prace R. Kulikowskiego (2003, s. 90-102), P. Dąbrowskiego (1975, 1977) oraz J. Szyrmera (1975), którzy jako pierwsi w kompleksowy sposób dokonali opisu sposobu pomiaru stopnia specjalizacji i koncentracji rolnictwa w Polsce. W niniejszym opracowaniu badania specjalizacji regionalnej - ze względu na strukturę towarowej produkcji rolnej - zostały przeprowadzone w oparciu o indeks specjalizacji regionalnej Krugmana. Indeks ten przedstawiany jest w trzech wariantach, jednak najpowszechniejszy jest pierwszy wariant, wedle którego indeks Krugmana oblicza się jako sumę różnic bezwzględnych między udziałami sektorowymi produkcji rolnej w określonym regionie $w$ produkcji rolnej ogółem tego regionu $\left(u_{r}^{i}\right)$ a udziałami produkcji rolnej według rodzajów ogółem w całkowitej produkcji rolnej $\left(u_{. j}\right)$ (Suchecki i Beck 2010):

$$
K_{r}=\sum_{i=}^{s}\left|u_{r}^{i}-u_{i}\right|
$$

Indeks specjalizacji Krugmana przyjmuje wartości z przedziału od 0 do 2. Wartość 0 oznacza, że brana pod uwagę struktura gospodarcza regionu jest identyczna jak przeciętna struktura w innych regionach. Natomiast wartości bliskie 2 wskazują na inność struktury gospodarczej regionu w porównaniu z przeciętną uzyskaną dla kraju (Krugman 1991; Miłek i Nowak 2014). Zatem im wyższa wartość indeksu, tym większa jest specjali- 
zacja danego regionu. Indeksy specjalizacji regionalnej produkcji rolnej w zbiorze rodzajów produkcji pozwalają na ustalenie, czy dany region w jakiś sposób korzysta z rozkładu produkcji według rodzajów.

\section{Specjalizacja polskich województw w zakresie produkcji rolnej}

Wyodrębniona struktura towarowej produkcji rolnej, roślinnej oraz zwierzęcej oraz ich dalszy podział na podtypy pozwoliły na przeprowadzanie analizy specjalizacji regionalnej produkcji rolnej województw w Polsce w latach 2004-2014. Z otrzymanych wyników można wywnioskować, że poziom specjalizacji województw ze względu na towarową roślinną produkcję w analizowanym okresie był przeciętnie zróżnicowany (tab. 1). Wartości indeksów Krugmana wahają się w przedziale od 0,125 (województwo pomorskie w 2010 r.) do 0,947 (województwo podlaskie w 2014 r.). Najniższe wartości indeksu w latach 2004-2014 otrzymano dla województwa pomorskiego, co przekłada się na występowanie najmniejszego stopnia specjalizacji tego województwa. Wynika to z pewnością z niskiej jakości gleb², co pociąga za sobą niski udział tej produkcji w ogólnej roślinnej produkcji rolnej. W latach 2004-2007 najwyższy indeks Krugmana otrzymano dla województwa małopolskiego (ok. 0,68). Kolejne lata przyniosły zmianę: pozycję lidera wśród województw najbardziej wyspecjalizowanych zajęło województwo podlaskie, dla którego indeks ten w latach 2008-2014 wyniósł przeciętnie 0,81. W przypadku tego województwa odnotowano również największe zróżnicowanie wartości wskaźników specjalizacji (w przedziale 0,579-0,947). Niewątpliwie województwo to wykorzystało swoją szansę i uzyskało najwięcej środków unijnych dostępnych w ramach PROW 2007-2013. Środki finansowe, jakie producenci rolni uzyskali w ramach różnych działań PROW, pozwoliły na zwiększenie specjalizacji w zakresie roślinnej produkcji rolnej, co przełożyło się w konsekwencji na wyższe dochody producentów.

Dla województw pomorskiego, małopolskiego, lubelskiego indeksy specjalizacji Krugmana były na tyle niskie, że struktura roślinnej produkcji rolnej nie różniła się istotnie od obserwowanej dla całego kraju. Trzy województwa Polski wschodniej (lubelskie, podlaskie i podkarpackie) uzyskały znacząco różne wartości indeksu: największą specjalizację odnotowano w województwie podlaskim (maksymalna wartość wynosi 0,947), a najmniejszą w województwie lubelskim (najniższa wartość - 0,167). Wydaje się, że brak specjalizacji, przekładający się na zróżnicowaną strukturę produkcji rolnej, może częściowo zminimalizować ryzyko produkcji. Natomiast województwa Polski zachodniej (lubuskie, zachodniopomorskie, dolnośląskie, opolskie) wykazują się większym podobieństwem ze względu na specjalizację w zakresie roślinnej produkcji rolnej.

${ }^{2}$ Gleby są bardzo zróżnicowane, przeważają gleby klasy III i IV. W skali 16 województw w kraju województwo pomorskie zajmuje 8 miejsce pod względem powierzchni ogólnej, 11 miejsce pod względem użytków rolnych i 6 miejsce pod względem powierzchni lasów; http://pomorskie.ksow.pl/rolnictwo.html 
Tabela 1. Specjalizacja regionalna roślinnej produkcji rolnej, indeks Krugmana

\begin{tabular}{|l|l|l|l|l|l|l|l|l|l|l|l|}
\hline Województwo & $\mathbf{2 0 0 4}$ & $\mathbf{2 0 0 5}$ & $\mathbf{2 0 0 6}$ & $\mathbf{2 0 0 7}$ & $\mathbf{2 0 0 8}$ & $\mathbf{2 0 0 9}$ & $\mathbf{2 0 1 0}$ & $\mathbf{2 0 1 1}$ & $\mathbf{2 0 1 2}$ & $\mathbf{2 0 1 3}$ & $\mathbf{2 0 1 4}$ \\
\hline Łódzkie & 0,539 & 0,531 & 0,528 & 0,569 & 0,556 & 0,459 & 0,549 & 0,569 & 0,581 & 0,527 & 0,567 \\
Mazowieckie & 0,436 & 0,421 & 0,417 & 0,437 & 0,516 & 0,453 & 0,543 & 0,541 & 0,402 & 0,445 & 0,492 \\
Małopolskie & 0,638 & 0,669 & 0,728 & 0,683 & 0,597 & 0,452 & 0,651 & 0,669 & 0,685 & 0,691 & 0,674 \\
Śląskie & 0,349 & 0,409 & 0,391 & 0,359 & 0,271 & 0,300 & 0,347 & 0,358 & 0,368 & 0,336 & 0,390 \\
Lubelskie & 0,236 & 0,230 & 0,236 & 0,242 & 0,272 & 0,188 & 0,243 & 0,167 & 0,225 & 0,286 & 0,221 \\
Podkarpackie & 0,475 & 0,512 & 0,581 & 0,574 & 0,508 & 0,408 & 0,539 & 0,559 & 0,569 & 0,490 & 0,551 \\
Podlaskie & 0,619 & 0,634 & 0,594 & 0,579 & 0,811 & 0,685 & 0,823 & 0,760 & 0,759 & 0,908 & 0,947 \\
Świętokrzyskie & 0,306 & 0,281 & 0,301 & 0,252 & 0,351 & 0,277 & 0,283 & 0,314 & 0,422 & 0,333 & 0,359 \\
Lubuskie & 0,335 & 0,306 & 0,385 & 0,284 & 0,318 & 0,302 & 0,537 & 0,404 & 0,350 & 0,540 & 0,453 \\
Wielkopolskie & 0,243 & 0,294 & 0,318 & 0,315 & 0,390 & 0,338 & 0,314 & 0,342 & 0,385 & 0,328 & 0,371 \\
Zachodniopomorskie & 0,365 & 0,327 & 0,409 & 0,372 & 0,283 & 0,304 & 0,309 & 0,204 & 0,345 & 0,302 & 0,261 \\
Dolnośląskie & 0,354 & 0,324 & 0,319 & 0,319 & 0,339 & 0,283 & 0,337 & 0,300 & 0,211 & 0,310 & 0,266 \\
Opolskie & 0,491 & 0,489 & 0,460 & 0,489 & 0,451 & 0,280 & 0,417 & 0,415 & 0,344 & 0,388 & 0,348 \\
Kujawsko-pomorskie & 0,463 & 0,428 & 0,443 & 0,477 & 0,467 & 0,388 & 0,444 & 0,429 & 0,532 & 0,400 & 0,425 \\
Pomorskie & 0,142 & 0,156 & 0,200 & 0,185 & 0,159 & 0,134 & 0,125 & 0,145 & 0,200 & 0,152 & 0,162 \\
Warmińsko-mazurskie & 0,461 & 0,478 & 0,501 & 0,479 & 0,455 & 0,490 & 0,463 & 0,592 & 0,611 & 0,392 & 0,511 \\
\hline
\end{tabular}

Źródło: Bank Danych Lokalnych, Główny Urząd Statystyczny.

Pod względem towarowej zwierzęcej produkcji rolnej największą specjalizację odnotowano w przypadku województwa lubuskiego, dla którego indeks Krugmana w latach 2004-2014 wyniósł przeciętnie 0,627 (tab. 2). Podstawowym kierunkiem produkcji zwierzęcej regionu lubuskiego jest produkcja drobiarska, która wyróżnia się na tle kraju pod względem udziału drobiu kurzego oraz indyków w produkcji zwierzęcej i stawia ten region na czołowym miejscu w Polsce. Bardzo niską specjalizacją w zakresie zwierzęcej produkcji rolnej charakteryzują się województwa: łódzkie (w latach 2004-2007 wartość indeksu oscylowała tu w granicach 0,004-0,114), podkarpackie (w latach 2009-2012 wartość wahała się w przedziale od 0,075 do 0,118). Województwa Polski centralnej (łódzkie, mazowieckie, świętokrzyskie) to regiony charakteryzujące się specjalizacją produkcji zwierzęcej na bardzo niskim poziomie. Najniższą wartość indeksu specjalizacji odnotowano dla województwa łódzkiego w 2004 r., najwyższą zaś dla mazowieckiego w 2013 r. Jednak wartości te są bardzo zróżnicowane - różnica pomiędzy wartością maksymalną a minimalną wynosi 0,288.

Można wskazać województwa, w których specjalizacja jest większa i te, gdzie jest mniejsza, ale w żadnym przypadku nie stwierdzono, że w którymś z województw specjalizacja jest tak duża, że nie produkuje się tam nic innego poza jednym typem produktu. Mogło to wynikać z konstrukcji miar specjalizacji względnej, dlatego do otrzymanych wyników należy podchodzić z ostrożnością, gdyż zastosowanie innej miary specjalizacji lub wybór innego obszaru referencyjnego może istotnie wpływać na rezultat badania. 
Tabela 2. Specjalizacja regionalna zwierzęcej produkcji rolnej, indeks Krugmana

\begin{tabular}{|l|l|l|l|l|l|l|l|l|l|l|l|}
\hline Województwo & $\mathbf{2 0 0 4}$ & $\mathbf{2 0 0 5}$ & $\mathbf{2 0 0 6}$ & $\mathbf{2 0 0 7}$ & $\mathbf{2 0 0 8}$ & $\mathbf{2 0 0 9}$ & $\mathbf{2 0 1 0}$ & $\mathbf{2 0 1 1}$ & $\mathbf{2 0 1 2}$ & $\mathbf{2 0 1 3}$ & $\mathbf{2 0 1 4}$ \\
\hline Łódzkie & 0,044 & 0,032 & 0,114 & 0,111 & 0,135 & 0,171 & 0,154 & 0,131 & 0,189 & 0,230 & 0,219 \\
Mazowieckie & 0,134 & 0,146 & 0,120 & 0,168 & 0,253 & 0,261 & 0,222 & 0,220 & 0,246 & 0,331 & 0,287 \\
Małopolskie & 0,215 & 0,177 & 0,236 & 0,216 & 0,196 & 0,369 & 0,385 & 0,454 & 0,386 & 0,358 & 0,406 \\
Śląskie & 0,113 & 0,076 & 0,108 & 0,172 & 0,329 & 0,220 & 0,287 & 0,273 & 0,295 & 0,280 & 0,307 \\
Lubelskie & 0,167 & 0,175 & 0,130 & 0,210 & 0,197 & 0,265 & 0,167 & 0,244 & 0,255 & 0,297 & 0,272 \\
Podkarpackie & 0,097 & 0,197 & 0,238 & 0,243 & 0,086 & 0,075 & 0,082 & 0,118 & 0,065 & 0,351 & 0,187 \\
Podlaskie & 0,255 & 0,256 & 0,251 & 0,238 & 0,302 & 0,277 & 0,445 & 0,249 & 0,183 & 0,257 & 0,277 \\
Świętokrzyskie & 0,088 & 0,147 & 0,083 & 0,149 & 0,044 & 0,118 & 0,147 & 0,236 & 0,236 & 0,067 & 0,182 \\
Lubuskie & 0,619 & 0,608 & 0,704 & 0,640 & 0,717 & 0,676 & 0,604 & 0,451 & 0,768 & 0,532 & 0,575 \\
Wielkopolskie & 0,167 & 0,193 & 0,194 & 0,181 & 0,237 & 0,231 & 0,176 & 0,175 & 0,139 & 0,115 & 0,136 \\
Zachodniopomorskie & 0,233 & 0,301 & 0,275 & 0,304 & 0,455 & 0,419 & 0,389 & 0,405 & 0,416 & 0,469 & 0,490 \\
Dolnośląskie & 0,160 & 0,344 & 0,486 & 0,318 & 0,215 & 0,286 & 0,245 & 0,349 & 0,505 & 0,414 & 0,478 \\
Opolskie & 0,112 & 0,119 & 0,096 & 0,112 & 0,125 & 0,137 & 0,174 & 0,201 & 0,262 & 0,163 & 0,225 \\
Kujawsko-pomorskie & 0,210 & 0,206 & 0,237 & 0,221 & 0,229 & 0,245 & 0,293 & 0,271 & 0,315 & 0,345 & 0,324 \\
Pomorskie & 0,438 & 0,463 & 0,488 & 0,547 & 0,598 & 0,269 & 0,301 & 0,370 & 0,373 & 0,232 & 0,346 \\
Warmińsko-mazurskie & 0,407 & 0,389 & 0,401 & 0,358 & 0,397 & 0,424 & 0,410 & 0,427 & 0,283 & 0,313 & 0,335 \\
\hline
\end{tabular}

Źródło: Bank Danych Lokalnych, Główny Urząd Statystyczny

Widoczny jest podział województw ze względu na strukturę towarowej produkcji rolnej (ryc. 1), który przejawia się w wyodrębnieniu województw z produkcją typowo roślinną oraz typowo zwierzęcą. Do pierwszej grupy województw należą województwa podlaskie, łódzkie, opolskie, małopolskie oraz podkarpackie. W latach 2004-2014 wartość indeksu Krugmana dla towarowej produkcji roślinnej w tych województwach utrzymywała się na najwyższych poziomach. Drugą grupę województw stanowią województwa zachodnio-pomorskie, dolnośląskie, lubuskie, pomorskie i warmińsko-mazurskie. W województwach tych widoczna jest specjalizacja towarowej produkcji rolnej w strukturze której dominuje produkcja zwierzęca. 
A - Produkcja roślinna

Crop output

2004

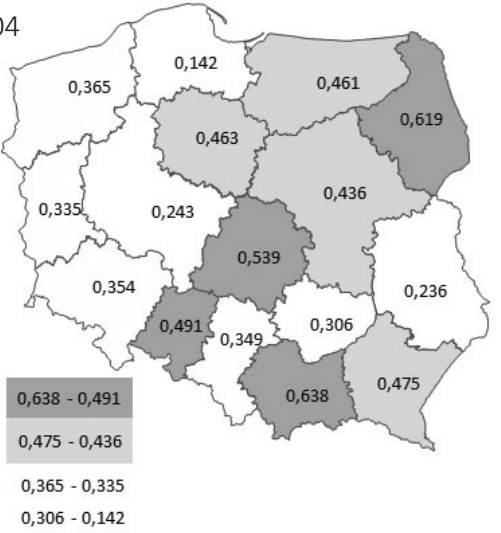

2007

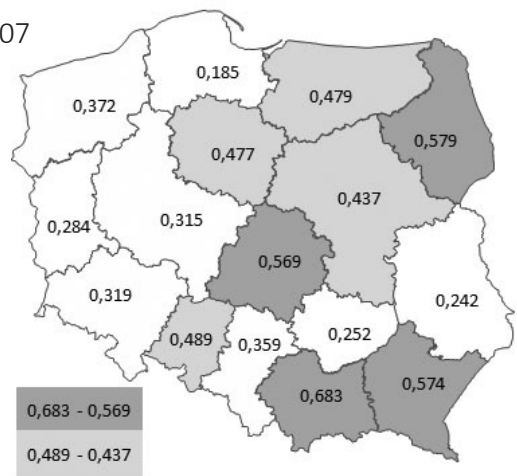

$0,372-0,315$

$0,284-0,185$

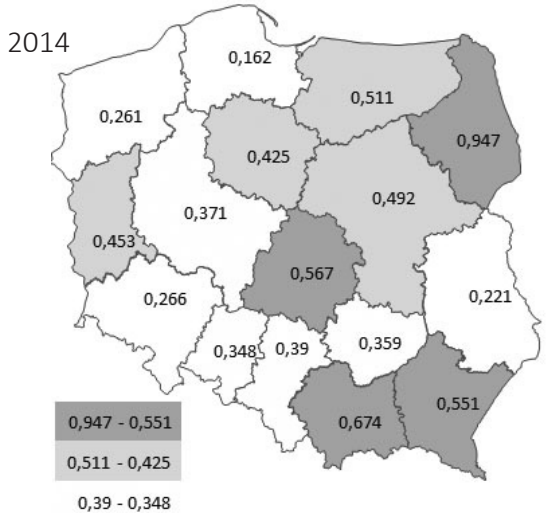

B - Produkcja zwierzęca

Animal output

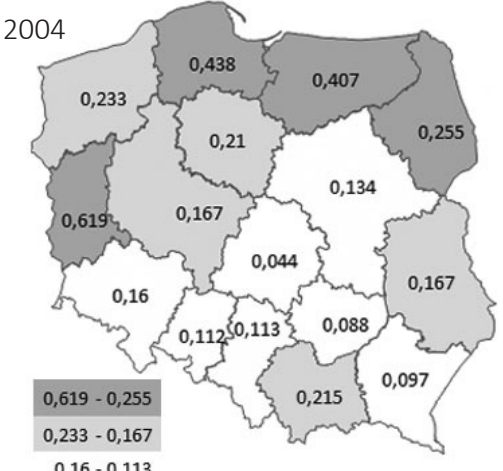

$0,112-0,044$

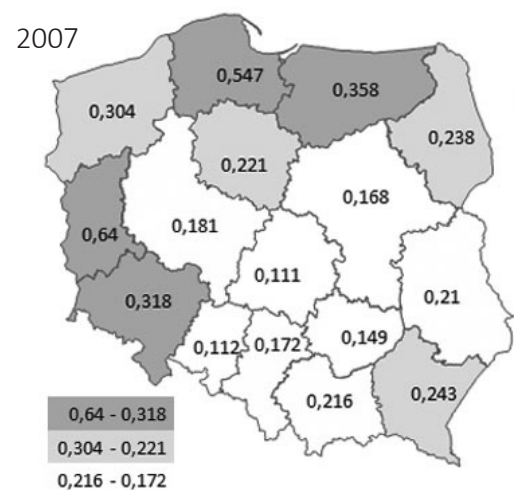

$0,168-0,111$

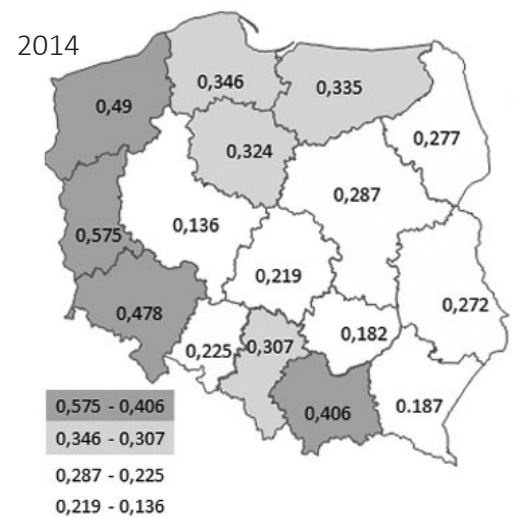

Ryc. 1. Podział województw ze względu na wartość indeksu Krugmana dla towarowej produkcji roślinnej i zwierzęcej w latach 2004, 2007, 2014

Źródło: opracowanie własne na podstawie danych GUS.

Voivodships by the Krugman index value for agricultural crop and animal output in years 2004, 2007, 2014

Source: own study based on CSO data. 


\section{Podsumowanie}

Badanie kierunku i stopnia specjalizacji województw ze względu na strukturę towarowej produkcji rolnej, przeprowadzone za pomocą indeksu Krugmana wykazało, że w większości przypadków charakteryzują się one przeciętnym stopniem specjalizacji. Oznacza to, że struktury roślinnej oraz zwierzęcej towarowej produkcji rolnej nie różnią się znacząco od obserwowanych dla całego kraju. Co prawda można wskazać województwa, gdzie ta specjalizacja może być większa bądź mniejsza, ale w żadnym przypadku nie można stwierdzić, że w którymś z województw jest ona tak duża, że nie produkuje się tam nic innego poza jednym typem produktu. Dodatkowo należy podkreślić, że województwa posiadające dobre warunki ekonomiczne, a niekoniecznie korzystne warunki przyrodnicze, osiągają lepsze wyniki w produkcji rolniczej. Jest to związane między innymi z faktem, iż województwa lepiej sytuowane w większym stopniu wykorzystują nowoczesne technologie produkcji oraz występuje tam wyższe zapotrzebowanie na wytworzone produkty rolnicze (większy popyt).

Rolnictwo ma duży potencjał produkcyjny wynikający z dużych zasobów siły roboczej oraz dużych zasobów ziemi. Pozycja konkurencyjna rolnictwa wynika po części ze stosunkowo niskich kosztów produkcji, postępującej terytorialnej specjalizacji produkcji oraz koncentracji w ważnych sektorach, takich jak mleko, zboża, oraz owoce i warzywa. Wyrazem tej konkurencyjności jest rosnący eksport produktów rolno-żywnościowych. Charakterystyczna dla struktury agrarnej jest rosnąca grupa gospodarstw żywotnych ekonomicznie i konkurencyjnych oraz malejąca, ale nadal liczna grupa gospodarstw małych i nierentownych. Natomiast specjalizacja produkcji daje możliwość optymalnego wykorzystania posiadanego parku maszynowego i zasobów pracy ludzkiej. Osiągane przychody pozwalają wówczas na finansowanie środków do produkcji rolnej (materiału siewnego i sadzeniakowego, nawozów mineralnych, środków ochrony roślin) oraz maszyn i urządzeń rolniczych na poziomie umożliwiającym konkurowanie z innymi gospodarstwami rolnymi w kraju i Unii Europejskiej.

\section{Literatura}

Bąk A., Krasowska M., Piotrowska M., Sobkiewicz A., Szymborska A., Chmielewski R., 2008, Doświadczenia i szanse regionów, Przegląd Regionalny, 2, Ministerstwo Rozwoju Regionalnego, Warszawa.

Dąbrowski P., 1977, Przestrzenne zróżnicowanie produkcji towarowej w Polsce (1960-1970), Studia KPZK PAN, 56.

Dąbrowski P., 1975, Regionalna specjalizacja produkcji rolniczej - kierunki Rozwoju, [w:] Osiagnięcia i problemy rozwoju produkcji polskiego rolnictwa, PWRiL, Warszawa.

Dziwulski M., 2012, Poziom specjalizacji produkcji żywca wieprzowego a efektywność gospodarstw rolniczych, J. Agribus. RuralDev, 1 (23), s. 37-47.

Grosse T.G., 2002, Przeglad koncepcji teoretycznych rozwoju regionalnego, Studia Regionalne i Lokalne, 1 (8), s. 25-48.

Landes D.S., 2000, Bogactwo i nędza narodów. Dlaczego jedni sq tak bogaci, a inni tak ubodzy, Muza SA., Warszawa.

Suchecki B., Beck C.H. (red.), 2010, Ekonometria przestrzenna. Metody i modele analizy danych przestrzennych, C.H. Beck, Warszawa. 
Kulikowski R. 2003, Syntetyczne metody badań produktywności i towarowości rolnictwa. Zastosowania w badaniach geograficznych w Polsce, Prace Geograficzne IGiPZ PAN, 187, Warszawa.

Krugman P., 1991, Geography and Trade, Institute of Economic Research Working Papers, 42/2014, The MIT Press, Cambridge.

Miłek D., Nowak P., 2004, Specjalizacja regionalna endogenicznym czynnikiem rozwoju polskich województw, The paper submitted to VIIIth International Conference on Applied Economics Contemporary Issues in Economy Under the title Market Or Government? Institute of Economic Research and Polish Economic Society Branch in Toruń, http://www.badania-gospodarcze.pl/ images/Working_Papers/2015_No_136.pdf

Ratajczak W. 2011, Raport Regionalny, Województwo wielkopolskie, Poznań, https://wrot.umww. pl/wrot-test/wp-content/uploads/2014/07/8.Raport-regionalny-wojew\%C3\%B3dztwa-wielkopolskiego.pdf

Szewczyk M., Tłuczak A., 2012, Economic Base of Opolskie Voivodship, 2008-2010, Journal of Interdisciplinary Research, Ad Alta 1, 3, s. 53-46.

Szyrmer J., 1975, Stopień specjalizacji rolnictwa. Próba zastosowania nowej metody mierzenia, Przegląd Geograficzny, 47, 1, s. 117-135.

\section{Summary}

Agriculture is a very specific sector of the economy, significantly different from other economic activities. One of the main distinguishing characteristics of agricultural production is its nature and strong dependence on the environmental conditions. These conditions determine to a large extent, the nature of agricultural production and its structure (crop/ animal). The accession of Poland to the EU in 2004 and access to EU funds (subsidies for farmers under different EU programs) often were the cause of change in the current profile of farm activities. Therefore, it seems reasonable to examine the changes in the specialization of agricultural production in Poland after 2004. The aim of this study is to answer the following questions: (1) Is there (and if, how strong) concentration of each of the main types of agricultural production in Poland, (2) What is the nature of this production in selected spatial units.

The analysis was conducted based on data on the volume of commodity agricultural production in years 2004-2014, the data used in the study was derived from the Local Data Bank of the Central Statistical Office in Poland. Specialization was determined using the Krugman index of regional specialization. 


\section{Informacja dla Autorów}

Studia Obszarów Wiejskich to wydawnictwo publikujące oryginalne opracowania naukowe z zakresu geografii społeczno-ekonomicznej, geografii wsi i przestrzennego zagospodarowania kraju w języku polskim lub/i angielskim. Zapraszamy Autorów do nadsyłania wartościowych artykułów. Przestrzeganie poniższych zaleceń formalnych usprawni prace redakcyjne i przyczyni się do szybszej publikacji nadsyłanych materiałów.

Uwagi ogólne. Zgłoszenie przez autora (ów) tekstu do Studiów Obszarów Wiejskich oznacza, że nie jest on przewidziany do druku w innym wydawnictwie. Jest także jednoznaczne z wyrażeniem zgody na jego rozpowszechnianie przez IGiPZ PAN w formie drukowanej i elektronicznej z wykorzystaniem licencji Creative Commons: uznanie autorstwa, 3.0 Polska.

Podstawowym sposobem przekazania materiałów do druku jest przesłanie tekstu i załączników na płycie CD na adres wskazany przez redakcję. Tekst artykułu powinien być napisany zwięźle, ale jasno, przy użyciu edytora MS WORD. Objętość artykułu nie powinna przekraczać 6000 słów. Wszystkie załączniki graficzne muszą być dostarczone w formie osobnych plików. Preferowany format dla danych liczbowych to MS EXCEL, a dla załączników graficznych pliki w formacie JPG, TIF, EPS, CDR*, AL* (*Wymagany zapis do edycji w starszych wersjach programów, na chwilę obecną: Corel Draw do wersji 14, Adobe llustrator do wersji 11).

Strona tytułowa. Na pierwszej stronie należy w kolejności umieścić: tytuł pracy w języku polskim, tytuł pracy w języku angielskim, imię i nazwisko autora/autorów (cyfry arabskie po nazwisku, umieszczane jako indeks górny, określają odp. afiliację), afiliację, adres (y), e-mail (e), zarys treści (maksymalnie 200 słów powinien zawierać: sformułowanie celu pracy/badań, identyfikację obiektu badań, przedmiotu rozważań, istotę stosowanej metody, najważniejsze wyniki i wnioski), słowa kluczowe (podaje się nie więcej niż 5 słów kluczowych).

Tekst artykułu pisany czcionką Calibri Light 10, interlinia 1,0. Nie należy nadawać odrębnych stylów znakowych i akapitowych oraz specyficznych wyróżnień (kolor, podkreślenia, itd.) fragmentom tekstu. W tekście opracowania, przy powoływaniu się na literaturę, należy podawać nazwisko autora oraz rok publikacji, np. (Nowak 2004; Kowalski 2005, 2007) lub według A. Nowaka (2006), a przy cytowaniu również numer strony, np. według A. Nowaka $(2006$, s. 6). W powołaniach na więcej prac tego samego autora, które ukazały się w tym samym roku, podaje się: (Nowak 1987a, b). W przypadku wspólnej publikacji dwóch autorów podaje się: (Kowalski i Nowak 1999), a trzech i więcej autorów: (Kowalski i in. 2006).

Podziękowania - opcjonalnie oraz ewentualna informacja o źródłach finansowania publikacji i wkładzie innych podmiotów w opracowanie publikacji (zgodnie z wymogami jakościowymi i standardami etycznymi opisanymi niżej) należy zamieścić po zasadniczym tekście.

Rysunki i fotografie z podpisami i objaśnieniami w j. polskim i angielskim powinny być zamieszczone w tekście, a ponadto dołączone w postaci osobnych plików posiadających numerację zastosowaną w tekście. Wymagana jest wysoka rozdzielczość rysunków i fotografii (min. 300 dpi w plikach rastrowych JPG lub TIF). Dopuszczalne formaty wektorowe (EPS, Al*, CDR*). Tytuł ryciny i źródło w języku polskim i angielskim powinny znajdować się poza rysunkiem, w pliku tekstowym. Objaśnienia znaków legendy w języku polskim i angielskim można zamieścić w obrębie ryciny lub poza nią. Rysunki i fotografie drukowane są w kolorze czarno-białym. Należy upewnić się, że po zastąpieniu ew. kolorów skalą szarości i przeskalowaniu do rozmiarów maksymalnie 12,5 x $20 \mathrm{~cm}$ będą one wystarczająco czytelne. Zalecany krój czcionki dla napisów będących częścią grafiki (bez możliwości edycji) to Calibri.

Tabele powinny być zamieszczone w tekście. Każda tabela powinna zawierać zwięzły tytuł (u góry) w języku polskim, kolejny numer i źródło danych (u dołu). Wszystkie skróty powinny być objaśnione (tytuł, źródło i objaśnienia należy dołączyć jedynie w pliku tekstowym). W komórkach tabeli nie powinny znajdować się znaki tabulacji (Tab) ani końca akapitu (Enter) - w razie potrzeby można korzystać ze znaku wymuszonego końca wiersza (Shift+Enter). Należy unikać nietypowego formatowania (jak wypełnienia kolorystyczne komórek, różne grubości linii, itd.).

Spis literatury ograniczony do literatury cytowanej, w porządku alfabetycznym, należy zamieścić poniżej tekstu artykułu według poniższego wzoru:

Artykuły w czasopismach i seriach wydawniczych:

Wójcik M., 2011, Współczesne kierunki i podejścia badawcze w geografii wsi, Przegląd Geograficzny, 83, 2, s. $163-185$.

Kulikowski R., 2013, Obszary wiejskie województwa podlaskiego w perspektywie 2050 roku, Studia Obszarów Wiejskich, 31, s. 129-142.

Rozdziały w pracach zbiorowych:

Zegar J.S., 2014, Typy społeczno-ekonomiczne indywidualnych gospodarstw rolnych według rodzaju gmin, [w:] R. Rudnicki. M. Kluba (red.), Zintegrowany rozwój obszarów wiejskich w świetle polityki Unii Europejskiej, t. 1, Rolnictwo i Wspólna Polityka Rolna, Wydawnictwo Naukowe Uniwersytetu Mikołaja Kopernika, Toruń, s. $57-73$.

Książki

Bański J., 2006, Geografia polskiej wsi, PWE, Warszawa. 
Streszczenie. Na końcu opracowania powinno być zamieszczone streszczenie w języku angielskim zweryfikowane przez native-speakera. Objętość streszczenia: około 250-400 słów.

Ocena artykułów i dopuszczenie ich do druku. Wszystkie artykuły niespełniające powyższych zasad będą odsyłane do poprawy. Artykuły podlegają ocenie przez dwóch recenzentów. W procesie recenzowania stosowane jest rozwiązanie, w którym autor (zy) i recenzenci nie znają swoich tożsamości (tzw. „double-blind review proces").Wynik recenzji będzie miał decydujący wpływ na możliwość opublikowania materiału w Studiach Obszarów Wiejskich.

Zasady dotyczące recenzowania w Studiach Obszarów Wiejskich

1. Do oceny każdej publikacji powołuje się co najmniej dwóch niezależnych recenzentów spoza jednostki, w której afiliowani są autorzy publikacji.

2. W przypadku tekstów powstałych w języku obcym, co najmniej jeden z recenzentów jest afiliowany w instytucji zagranicznej innej niż narodowość autora pracy.

3. W procesie recenzowania stosowane jest rozwiązanie, w którym Autor (zy) i recenzenci nie znają swoich tożsamości (tzw. double-blind review proces).

4. Wyznaczając recenzentów redakcja wydawnictwa zachowuje ponadto zasadę zapobiegania konfliktom interesów między recenzentem a autorem.

5. Recenzje mają formę pisemną i kończą się jednoznacznym wnioskiem do dopuszczenia artykułu do publikacji lub jego odrzucenia, względnie warunkowego dopuszczenia tekstu do publikacji po jego poprawieniu przez autora według uwag zawartych w recenzji. W takiej sytuacji recenzent może zastrzec sobie prawo do ponownego zrecenzowania pracy, po dokonaniu przez autora poprawek wskazanych w pierwszej recenzji. Do publikacji dopuszczane będą prace posiadające dwie pozytywne recenzje (zawierające wniosek o dopuszczenie do publikacji) - wzór recenzji poniżej.

6. Zasady kwalifikowania lub odrzucenia publikacji oraz formularz recenzji są podane do publicznej wiadomości na stronie internetowej wydawnictwa.

7. Nazwiska recenzentów nie są publikowane przy poszczególnych artykułach

Studia Obszarów Wiejskich

ARKUSZ RECENZII

Tytuł recenzowanego artykułu

1. Czy zagadnienie przedstawione w artykule jest istotne pod względem naukowym i może zainteresować szersze grono czytelników? Czy praca przedstawia oryginalne materiały autorskie, stanowi syntezę czy przegląd badań?

2. Czy tematyka artykułu odpowiada tematyce tomu i profilowi Studiów Obszarów Wiejskich?

3. Czy sposób przedstawienia tematu jest prawidłowy, to znaczy (odpowiedź: Tak lub Nie)

- czy tytuł dokładnie odpowiada treści?

- czy zagadnienie zostało przedstawione w sposób logiczny?

- czy wnioski wynikają z treści pracy?

- czy odpowiednie pozycje literatury zostały uwzględnione?

- czy ilustracje (tabele wykresy, mapy) są czytelne i wystarczające

4. Sugerowane poprawki (rozwinięcie na odwrotnej lub osobnej stronie). Drobne poprawki mogą być zaznaczone w tekście artykułu.

\section{WNIOSEK:}

Ocena artykułu:

Bardzo dobra

$\square$ Dobra

口 Przeciętna

口 Temat interesujący, ale słabo przedstawiony

Artykuł warto opublikować (właściwe podkreślić):

- w wersji przedstawionej przez autora (-ów)

- z ewentualnymi drobnymi poprawkami sugerowanymi przez recenzentów i/lub redakcję

- po dokonaniu zasadniczych zmian sugerowanych przez recenzentów i redakcję

- artykuł nie nadaje się do publikacj

Wymogi jakościowe i standardy etyczne. W trosce o dochowanie najwyższych standardów redakcyjnych oraz w celu zapobieżenia nierzetelności w publikacjach naukowych określanych jako tzw. ghostwriting i guest authorship Redakcja Studiów Obszarów Wiejskich wymaga od autorów ujawniania informacji o podmiotach przyczyniających się do powstania publikacji (wkład merytoryczny, rzeczowy, finansowy etc.). W tym celu zobowiązuje się autorów do zachowania następujących standardów podczas przygotowywania tekstów składanych do publikacji: 1) w przypadku publikacji naukowych, które nie zostały wykonane samodzielnie, tzn. opracowano je we współautorstwie lub z wykorzystaniem pomocy wyspecjalizowanego podmiotu (osoby fizycznej lub praw- 
nej), w końcowej części pracy (w punkcie: „Podziękowania”) należy zawrzeć notę, w której ujawniany jest wkład poszczególnych autorów (współautorów) w powstanie publikacji (artykułu, monografii). Oznacza to konieczność podania ich afiliacji oraz kontrybucji, tj. informacji kto jest autorem koncepcji, założeń, zastosowanych metod, protokołu itp., wykorzystywanych w toku pracy badawczej - przygotowywania publikacji; główną odpowiedzialność ponosi autor zgłaszający manuskrypt. 2) Autor/współautorzy podają ponadto informację o ewentualnych źródłach finansowania publikacji, wkładzie instytucji naukowo-badawczych, stowarzyszeń i innych podmiotów w opracowanie publikacji (financial disclosure). Redakcja wydawnictwa informuje, że wszelkie przejawy nierzetelności naukowej, zwłaszcza łamania i naruszania zasad etyki obowiązujących w nauce, w tym wykryte przypadki ghostwriting, guestauthorship będą dokumentowane i oficjalnie demaskowane, włącznie z powiadomieniem odpowiednich podmiotów (instytucje zatrudniające autorów, towarzystwa naukowe, stowarzyszenia edytorów naukowych itp.).

Z ghostwriting mamy do czynienia wówczas, gdy ktoś wniósł istotny wkład w powstanie publikacji, bez ujawniania swojego udziału jako jeden z autorów lub bez wymieniania jego roli w Podziękowaniach zamieszczonych w publikacji.

Z guest authorship (honorary autorship) mamy do czynienia wówczas, gdy udział autora jest znikomy lub w ogóle nie miał miejsca, a pomimo to jest autorem/wspłautorem publikacji.

Wersja pierwotna. Wersja papierowa i elektroniczna są tożsame, jednakże Redakcja wskazuje wersję papierową jako wersję pierwotną czasopisma.

\section{Adres Redakcji}

ul. Twarda 51/55, 00-818 Warszawa

tel. (+48 22) 69788 34, fax (+48 22) 6206221

e-mail: b.solon@twarda.pan.pl

Redaktor Naczelny Studiów Obszarów Wiejskich 


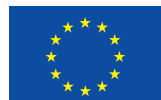
Europejski Fundusz Rolny na rzecz
Rozwoju Obszarów Wiejskich
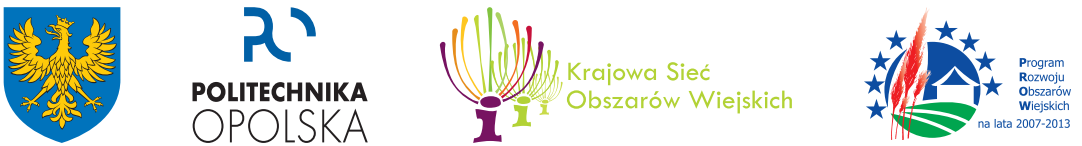

Europejski Fundusz Rolny na rzecz Rozwoju Obszarów Wiejskich: Europa inwestująca w obszary wiejskie

Konferencja XXXI Seminarium Geografii Wsi: Obszary wiejskie - pierwsza dekada w Unii Europejskiej i nowa perspektywa

współfinansowana ze środków Unii Europejskiej w ramach Schematu III Pomocy Technicznej Programu Rozwoju Obszarów Wiejskich na lata 2007-2013 Instytucja Zarządzająca Programem Rozwoju Obszarów Wiejskich na lata 2007-2013: Minister Rolnictwa i Rozwoju Wsi

Publikacja opracowana na zlecenie Politechniki Opolskiej

\title{
STUDIA \\ OBSZARÓW \\ WIEJSKICH
}

\section{tom 42}

\author{
Józef Stanisław ZEGAR \\ Esej o rozwoju rolnictwa i wsi we współczesnych uwarunkowaniach \\ Krystian HEFFNER • Brygida KLEMENS \\ Potencjały i strefy problemowe w zakresie świadczenia usług publicznych na obszarach wiejskich w skali \\ regionalnej
}

\section{Gabriela CZAPIEWSKA}

Ocena trendów rozwoju obszarów wiejskich Pomorza w pierwszej dekadzie po akcesji do Unii Europejskiej

\section{Ewa PAtKA-ŁEBEK}

Współpraca gospodarstw agroturystycznych z lokalnymi stowarzyszeniami wspierającymi rozwój turystyki na przykładzie województwa świętokrzyskiego

\section{Diana ROKITA-POSKART}

Aktywność gospodarcza na migracyjnych i niemigracyjnych obszarach wiejskich województwa opolskiego Krystyna KUROWSKA • Marek OGRYZEK • Hubert KRYSZK

Kształtowanie się cen nieruchomości rolnych po wstąpieniu Polski do Unii Europejskiej na przykładzie Agencji Nieruchomości Rolnych OT Olsztyn

Roman RUDNICKI • Łukasz WIŚNIEWSKI

Cechy produkcyjne rolnictwa a poziom absorpcji środków wspólnej polityki rolnej w Polsce Michał JASIULEWICZ

Dotychczasowa realizacja Narodowego Celu Wskaźnikowego w zakresie odnawialnych źródeł energii na przykładzie biomasy w Polsce i perspektywa osiągnięcia celu w 2020 r.

\section{Dorota JANISZEWSKA • Luiza OSSOWSKA}

Społeczno-ekonomiczne uwarunkowania rolnictwa dla produkcji energii odnawialnej z biomasy rolniczej w Polsce

\section{Stanisława SOKOŁOWSKA • Anna BISAGA}

Wspólna Polityka Rolna i jej kapitał instytucjonalny w ocenie użytkowników towarowych gospodarstw rolnych regionu opolskiego

\section{Jolanta KLUBA}

Wpływ instrumentów Wspólnej Polityki Rolnej na gospodarstwa indywidualne w województwie opolskim w opinii rolników

\section{Dawid BAŁA}

Wpływ instrumentów Wspólnej Polityki Rolnej na rozwój grup producentów rolnych w Polsce w ujęciu regionalnym

\section{Roman RUDNICKI • Łukasz WIŚNIEWSKI}

Przemiany poziomu i struktury mechanizacji rolnictwa polskiego w świetle analizy porównawczej wyników spisów powszechnych rolnictwa z lat 2002 i 2010

\section{Anna DUBOWNIK・Roman RUDNICKI}

Reforma rynku cukru Unii Europejskiej i jej wpływ na uprawę buraków cukrowych i produkcję cukru w Polsce Agnieszka GIL

Stan i przyszłość gospodarstw ekologicznych w drobnoobszarowym rolnictwie województwa małopolskiego Agnieszka TŁUCZAK

Regionalna specjalizacja produkcji rolnej w Polsce 